\title{
Film-Rupture Mechanism of Stress Corrosion
}

\author{
Hugh L. Logan
}

\begin{abstract}
The atmospherically formed protective films were removed by abrasion in an argon atmosphere from surfaces of an aluminum alloy, two brasses, a magnesium alloy, and lowcarbon and stainless steels. The resulting surfaces were 0.12 to 0.76 volt more negative with respect to a calomel electrode than surfaces prepared and measured under normal atmospheric conditions. Appreciable changes in electrochemical solution potentials of notched specimens, stressed in tension, occurred at or just above stresses at which the true stress-true strain curves deviated from the modulus lines. These changes in potential were caused by rupturing of the protective films at the roots of the notches and were of the order of 0.16 to 0.70 volt at failure, depending on the material. Stress corrosion is postulated to occur in corrosive media, at stresses sufficient to rupture the protective film, by electrolytic action between the filmed (cathodic) and film-free (anodic) areas.
\end{abstract}

\section{Introduction}

Stress-corrosion cracking has been defined as the "spontaneous failure of metal by cracking under the combined action of corrosion and stress, residual or applied" [1]. ${ }^{1}$ Service failures have frequently resulted from residual stresses set up in the material or structure during fabrication. These stresses may result from the spinning or deep drawing of sheet brass, the work-hardening of aluminum-alloy tubing, the pressing of oversized bushings into aluminumalloy fittings, the riveting or welding of steel structures, or even as the result of the application of excessive torques in the assembling of brass-pipe structures [2]. Stress-corrosion cracking may be either intercrystalline, as in aluminum alloys, alpha brass, and low-alloy steels, or transcrystalline, as is usually the case in magnesium-base alloys and the austenitic stainless steels.

It is agreed by most workers in the field that some degree of stress-corrosion cracking can be produced in many alloys and commercially pure metals by the proper combinations of stresses and corrosive media. The ASTM-AIMME Symposium on Stress-Corrosion Cracking of Metals [3], published in 1944, gives an excellent summary of work in the field to that date. A number of papers have also appeared in recent years [4 to 8,10$]$ that contain excellent bibliographies. For the most part, the data in the literature are from investigations of the relative susceptibilities of various materials to stress-corrosion cracking, susceptibilities of particular materials to stress corrosion in specific corrosive media, or susceptibilities of particular materials to stress corrosion after various mechanical or thermal treatments.

The purpose of this investigation was to study the mechanism of stress corrosion and not to determine the relative susceptibilities of various materials to stress corrosion. Recently the various theories of the mechanism of stress corrosion were summarized by Harwood [10]. Of these theories the "Generalized theory of stress corrosion" proposed by Mears, Brown, and Dix [11], the "Mechanical theory" of

\footnotetext{
Figures in brackets indicate the literature references at the end of this paper.
}

Keating [5], and the "Film rupture theory", or better, "Film rupture mechanism," are pertinent to the present paper. It is considered in this paper that the "Film rupture mechanism" and the "Mechanical theory" are logical parts of the Generalized theory.

In the Generalized theory, corrosion is postulated to occur by an electrochemical mechanism along localized paths that are anodic to the surrounding metal. There will be stress concentrations at the bases of localized corroded areas; the deeper the attack and ... "the smaller the radius at the base of the path the greater would be the stress concentration. Such a condition would act to pull the metal apart along more or less continuous paths. At sufficient concentrations of stress, the metal might start to tear apart by mechanical action . . . the tearing action described above would expose fresh metal, unprotected by films, to the action of the corrosive environment. Because this freshly exposed metal is more anodic, an increase in current from the base of the localized path to the unaffected surface would be expected ...". It is seen from this quotation that Mears and his coworkers [11] postulate a mechanism in which protective films on metal surfaces are ruptured. Keating [5] suggested that each advancing section of the crack in time encounters an obstacle in the form of a nonmetallic inclusion, lattice discontinuity, or unfavorably orientated grain boundary . In each case, the result may be reduction in the stressconcentration effect to a level at which cracking cannot proceed. Such a process would explain branching of stress-corrosion cracks, sudden changes in direction at grain boundaries, etc. Gilbert and Haden [12] report the results of an investigation on an aluminum alloy containing 7 percent of magnesium in which they found that the cracking process was not continuous but stepwise.

There are few published data from which the electrochemical solution potential of the freshly torn metal at the root of the crack can be estimated. Work at the National Bureau of Standards as early as 1940 showed that the solution potential of freshly quenched or freshly abraded $24 \mathrm{~S}-\mathrm{T}$ aluminum-alloy sheet was much more electronegative (anodic) than that of the same material permitted to stand for 
some minutes before measurements were made [13]. Similar results were recently obtained at the Bureau on 18-percent-Cr-8-percent-Ni austenitic stainless steels. Mears and Brown [14] report a solution potential greater than $-3.0 \mathrm{v}$ for commercially pure aluminum from which the film was removed by scratching the surface with a glass stylus in the electrolyte. Druet and Jacquet [15] report values of $-0.75 \mathrm{v}$ for mechanically polished specimens containing 99.99 percent of aluminum (presumably with a protective film intact) and $-1.384 \mathrm{v}$ for the same material with measurements made immediately after electrolytic polishing.

The author is not aware of any data giving the magnitude of changes in solution potential produced by rupture of protective films on the metals or alloys that are particularly susceptible to stress corrosion. Such data are necessary to establish the validity of the so-called film rupture process in the generalized theory of stress corrosion. In the early phases of the investigation of the mechanism of stress corrosion, the following have been determined and are reported in this paper: (a) the electrochemical solution potentials of several alloys free from the protective effects of films, ${ }^{2}$ and (b) relationships between the applied stresses and the electrochemical solution potentials of these alloys.

\section{Materials and Methods of Test}

The materials used in this investigation were $24 \mathrm{~S}$ $\mathrm{T} 4$ aluminum alloy, 70-percent-Cu-30-percent-Zn

${ }^{2}$ It is recognized that contact of an electrolyte, at least with the aluminum and
magnesium alloys studied, may produce a protective film on the metal surfaces. cartridge brass, 61-percent-Cu-36-percent-Zn-3-percent- $\mathrm{Pb}$ leaded brass, AZ31f magnesium alloy, lowcarbon steel, and type 302 stainless steel. The chemical compositions are given in table 1 . The aluminum alloy, the leaded brass, and the steels were obtained commercially. The magnesium alloy was supplied by the Dow Chemical Co., and the cartridge brass was made in the Bureau's Experimental Foundry from electrolytic copper and 99.99 percent zinc. Prior to machining of the specimens, the materials were heat treated as follows: (a) The aluminum-alloy stock was solution heat-treated at $920^{\circ} \pm 10^{\circ} \mathrm{F}$, and quenched in water at approximately $70^{\circ} \mathrm{F}$, (b) the cartridge brass was rolled to a diameter of about 0.62 in. and then annealed for 1 hour at $1,560^{\circ} \mathrm{F}$, after which the Brinell hardness number was 66 and the grain size approximately $0.025 \mathrm{~mm}$, (c) the low-carbon steel, originally in the cold-rolled condition, was heated to $1,625^{\circ} \mathrm{F}$ and cooled with the furnace, (d) the stainless steel was heated to $1,950^{\circ} \mathrm{F}$ and quenched in cold water. The magnesium alloy, in the form of an extruded rod $1 / 2$ in. in diameter, and the leaded-brass rod, $1 / 2$ in. in diameter, were used as received. The magnesium alloy evidently had been extruded at a sufficiently high temperature that the metal had recrystallized following extrusion. The leaded brass had a Brinell hardness number of 113 and a grain size of 0.015 to $0.025 \mathrm{~mm}$. The tensile properties, as determined on subsize (0.355-in. diameter) ASTM round tensile specimens, are given in table 2 .

When the protective film on $24 \mathrm{~S}-\mathrm{T} 4$ aluminum alloy is broken in air, it tends to repair itself quite rapidly. Therefore, specimens were prepared by

TABLE 1. Chemical composition of metals used

\begin{tabular}{|c|c|c|c|c|c|c|c|c|c|c|c|c|c|}
\hline Material & Al & $\mathrm{C}$ & $\mathrm{Cr}$ & $\mathrm{Cu}$ & $\mathrm{Fe}$ & $\mathrm{Pb}$ & $\mathrm{Mn}$ & $\mathrm{Mg}$ & $\mathrm{Ni}$ & $\mathrm{P}$ & $\mathrm{Si}$ & $\mathrm{S}$ & $\mathrm{Zn}$ \\
\hline $\begin{array}{l}\text { 24S aluminum alloy a } \\
\text { Cartridge brass } \\
\text { Leaded brass } \\
\text { AZ31 magnesium alloy a } \\
\text { Low-carbon steel } \\
\text { Type } 302 \text { stainless steel }\end{array}$ & $\begin{array}{c}\% \\
2.9 \\
\end{array}$ & $\begin{array}{c}\% \\
0.17 \\
.072\end{array}$ & $\begin{array}{c}\% \\
19.17\end{array}$ & $\begin{array}{c}\% \\
3.9 \\
69.4 \\
61.2 \\
0.01 \\
-\end{array}$ & $\begin{array}{c}\% \\
0.4 \\
.003 \\
\end{array}$ & $\begin{array}{r}\% \\
3.0 \\
\end{array}$ & $\begin{array}{c}\% \\
0.6 \\
.4 \\
.81 \\
.38\end{array}$ & \begin{tabular}{c}
$\%$ \\
1.4 \\
\hdashline \\
\\
\\
\end{tabular} & $\begin{array}{c}\% \\
8.63 \\
\end{array}$ & $\begin{array}{c}\% \\
0.005 \\
017\end{array}$ & $\begin{array}{l}\% \\
0.1 \\
.03 \\
.019 \\
.297\end{array}$ & $\begin{array}{c}\% \\
0.024 \\
013\end{array}$ & $\begin{array}{r}\% \\
\text { b } 30.6 \\
\text { b } 35.8 \\
1.0 \\
\end{array}$ \\
\hline
\end{tabular}

a Determined spectroscopically. b By difference. 'Manufacturer's analysis.

TABLE 2. Mechanical properties of metals used

\begin{tabular}{|c|c|c|c|}
\hline Material & $\begin{array}{c}\text { Ultimate } \\
\text { tensile } \\
\text { strength }\end{array}$ & $\begin{array}{c}\text { Yield } \\
\text { strength }\end{array}$ & Elongation \\
in 1.4 in.
\end{tabular}

abrading them with "400 aloxite" metallographic polishing paper, and all measurements were made in an argon atmosphere ${ }^{3}$ in a dry box. In making measurements, drops of the desired electrolyte were

${ }^{3}$ An analysis of the argon by the mass spectrograph method showed 0.2 percent of $\mathrm{N}_{2}$ as the only detectable impurity. placed on the prepared surface and brought into electric contact with a calomel electrode of the saturated $\mathrm{KCl}$ type by means of an agar-agar bridge. Potential measurements were made with a $\mathrm{pH}$ meter, or for values in excess of $1.3 \mathrm{v}$, with the $\mathrm{pH}$ meter in series with a L\&N type $\mathrm{K}$ potentiometer.

It was recognized that the preparation of the specimen surfaces by abrasion left the surfaces to be measured in the cold-worked condition and might produce phase changes in the stainless steel. In some earlier work at the Bureau the author reduced the thickness of some $24 \mathrm{~S}-\mathrm{T} 4$ aluminum-alloy sheet approximately 5 percent without appreciable changing its solution potential. Druet and Jacquet [15] showed that severely cold-worked high-purity aluminum was only about $0.04 \mathrm{v}$ more negative than the annealed material. The author has seen no data on 
the effect of cold-work on the solution potentials of other materials studied nor no the effect of a phase change on the solution potential of the stainless steel.

Stress-electrochemical solution potential relationships were obtained on notched specimens made in accordance with the drawing in figure 1 . The specimens were covered, except for the threaded ends, with two coats of Glyptal red enamel. After the enamel had dried it was cut through by means of a razor blade so as to expose an extremely narrow width of metal around the specimen at the root of the notch. The specimens were placed in cells in a tensile-testing machine, figure 2, with a calomel electrode placed directly in the cell if potassium chloride was used as the electrolyte or in a beaker connected to the cell by an agar-agar bridge if some other electrolyte was used. The specimens were stressed to failure in the corroding solution, and the electrochemical solution potentials that corresponded to given loads were determined either with a $\mathrm{pH}$ meter used as a vacuum-tube voltmeter or a Miller multimeter (used as a high-resistance potentiometer). The free cross-head speed of the testing machine was held between 0.05 and $0.10 \mathrm{in} . / \mathrm{min}$. In order to obtain true stress-true strain and load-true stress

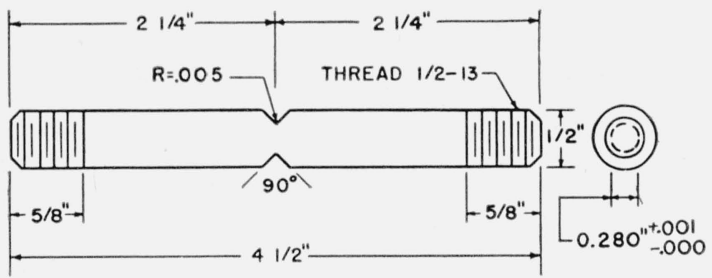

FIGURE 1. Details of notched specimens.

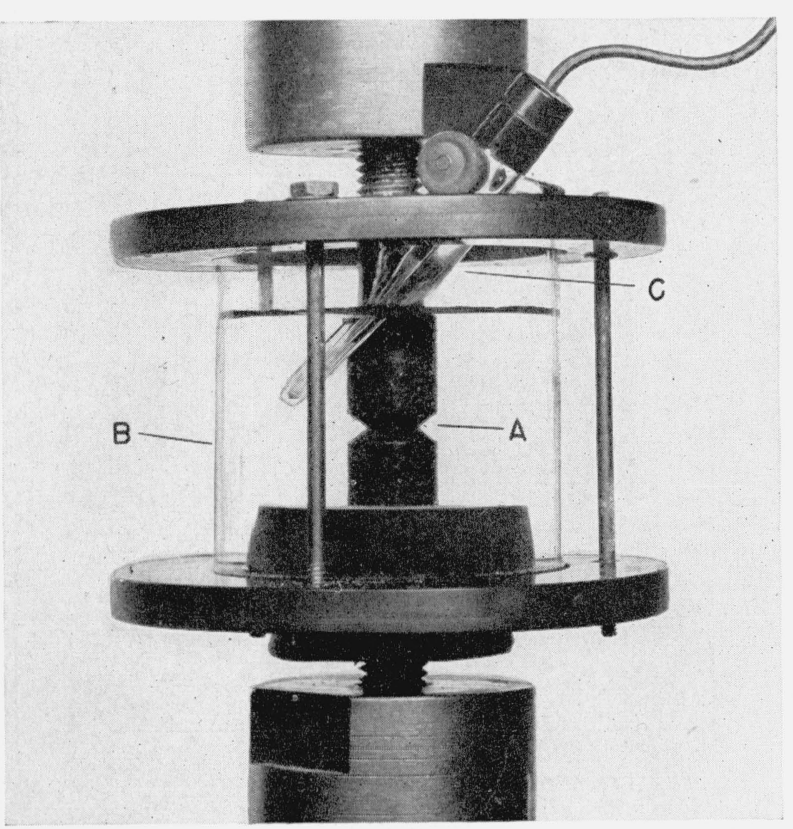

Figure 2. Notched specimen $(A)$ in place in cell, (B) in testing machine.

Electrode (C) was placed directly in cell if potassium chloride was the corrodent, otherwise an agar-agar bridge was used. relationships, three or more additional notched specimens of each material were broken in the uncorroded condition. ${ }^{4}$ True stress-electrochemical solution potential relationships were then obtained by combining load-true stress and load-electrochemical solution potential data.

\section{Results and Discussion}

\subsection{Electrochemical Solution Potentials of the Metals}

The different electrolytes used and the electrochemical solution potentials of the various materials, determined in air and in argon, are given in table 3. All values are in terms of a calomel electrode of the saturated $\mathrm{KCl}$ type and were determined at approximately $25^{\circ} \mathrm{C}$. The values reported for atmospherically formed filmed surfaces were equilibrium values obtained by immersion of the prepared surfaces in their specific electrolytes; the values reported for the specimens prepared in argon were instantaneous maxima and not necessarily equilibrium values. These values are given inasmuch as they represent the conditions under which changes in electrochemical solution potential values reported in a later section of this paper were obtained.

TABLE 3. Electrochemical solution potentials (with respect to calomel electrode of saturated $\mathrm{KCl}$ type) of materials with surfaces prepared and measurements made in air or argon

\begin{tabular}{|c|c|c|c|}
\hline \multirow{2}{*}{ Material } & \multirow{2}{*}{ Electrolyte } & \multicolumn{2}{|c|}{$\begin{array}{l}\text { Electrochemical } \\
\text { solution } \\
\text { potentials in- }\end{array}$} \\
\hline & & Air & Argon \\
\hline 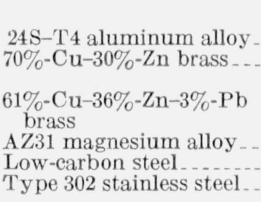 & $\begin{array}{l}\mathrm{KCl} \text { (saturated) } \\
5 \% \mathrm{NH}_{4} \mathrm{OH}+ \\
\left.5 \% \mathrm{OH}_{4}\right)_{2} \mathrm{CO}_{3} \\
3.5 \% \mathrm{NaCl}_{2} \% \mathrm{~K}_{2} \mathrm{CrO}_{4} \ldots \\
5 \% \mathrm{NH}{ }_{4} \mathrm{NO}_{3} \ldots \\
\mathrm{KCl} \text { (saturated) }\end{array}$ & $\begin{array}{r}\text { Volt } \\
-0.67 \\
-.47 \\
-.39 \\
-1.51 \\
-0.60 \\
-.28\end{array}$ & $\begin{array}{r}\text { Volt } \\
-1.43 \\
-0.96 \\
-.98 \\
-1.645 \\
-0.72 \\
-.78\end{array}$ \\
\hline
\end{tabular}

The data indicate that, under normal atmospheric conditions, protective films are formed on the surfaces of these alloys. These filmed materials are in some cases as much as $0.76 \mathrm{v}$ more electropositive than the same materials with surfaces prepared under argon. The largest differences in potential are found on the aluminum alloy, the brasses, and the stainless steel, all of which are relatively corrosion-resistant materials. Those materials that corrode more readily, such as low-carbon steel and the magnesium alloy, had very much smaller differences in potential between filmed and unfilmed surfaces.

In order to determine whether the difference in solution potential of the cartridge brass was due to the formation of an oxide film or to some other cause, the following investigation was carried out. A

${ }_{4} 1$ he use of notched specimens, of course, introduces stress concentrations of undetermined magnitude at the root of the notch. The maximum stress at the root of the notch is a function not only of the geometry of the specimen, but also of the aprlied stress. Although the radii of the notches used were small (approximately 0.005 in.), they were nevertheless large compared to those at the roots of stress-corrosion cracks in many materials. 
specimen was placed in the dry box, and a surface was prepared and measured under argon. Approximately 20 percent of the argon was then replaced by dry oxygen, and additional measurements were made on the same surface. The experiment was repeated with wet oxygen, wet carbon dioxide, and dry ammonia gas. The results are given in table 4 .

TABLE 4. Electrochemical solution potentials of $70 \%-\mathrm{Cu}-30 \%$ $\mathrm{Zn}$ brass with surfaces prepared in an argon atmosphere and measurements made in a mixed atmosphere

Electrolyte was $5 \% \mathrm{NH}_{4} \mathrm{OH}+5 \%\left(\mathrm{NH}_{4}\right)_{2} \mathrm{CO}_{3}$

\begin{tabular}{|c|c|}
\hline Atmosphere & $\begin{array}{l}\text { Electrochemical } \\
\text { solution } \\
\text { potential }\end{array}$ \\
\hline $\begin{array}{l}\text { Argon } \\
80 \% \text { argon }+20 \% \text { dry } \mathrm{O}_{2} \\
80 \% \text { argon }+20 \% \text { wet } \mathrm{O}_{2} \\
80 \% \text { argon }+20 \% \text { wet } \mathrm{CO}_{2} \\
80 \% \text { argon }+20 \% \text { dry } \mathrm{NH}_{3} \\
\text { Air }\end{array}$ & $\begin{array}{l}\text { Volt } \\
-0.96 \\
-.45 \text { to }-.50 \\
-.45 \text { to }-.50 \\
-.72 \text { to }-.78 \\
-.53 \text { to }-.61 \\
-.47\end{array}$ \\
\hline
\end{tabular}

It will be noted that in every case the solution potential was more positive after the addition of the second gas, the change being most marked in the case of oxygen, either dry or wet. In the atmosphere containing ammonia, the surface of the alloy adjacent to drops of liquid used in making the measurements became tarnished; its final potential was $-0.31 \mathrm{v}$ compared to $-0.47 \mathrm{v}$ for brass measured in air. Measurements made on the surfaces of brass specimens covered with a blue corrosion product after exposure to an atmosphere containing ammonia, carbon dioxide, air, and water vapor were $0.75 \mathrm{v}$ more electropositive than film-free surfaces of the same alloy.

\subsection{Stress-Electrochemical Solution Potential Relationships}

The relationships between the true stresses and electrochemical solution potentials of the materials are shown in figures 3 to 8 . The maximum values of the potentials were usually obtained just at the failure of the specimen as the result of the exposure of large areas of unfilmed material. These values are of course not shown on the figures but are given in table 5. In any measurement of electrochemical solution potentials the measured potentials are

TABLE 5. Maximum change in electrochemical solution potential with stress.

\begin{tabular}{|c|c|c|}
\hline Material & Electrolyte & $\begin{array}{l}\text { Change in } \\
\text { electrochem- } \\
\text { ical solution } \\
\text { potential }\end{array}$ \\
\hline $\begin{array}{l}24 \mathrm{~S}-\mathrm{T} 4 \text { aluminum alloy } \\
70 \%-\mathrm{Cu}-30 \%-\mathrm{Zn} \text { Brass } \\
61 \%-\mathrm{Cu}-36 \%-\mathrm{Zn}-3 \%-\mathrm{Pb} \\
\text { brass. } \\
\text { AZ31 magnesium alloy } \\
\text { Low-carbon steel } \\
302 \text { stainless steel }\end{array}$ & $\begin{array}{l}\text { Saturated } \mathrm{KCl} \\
5 \% \mathrm{NH}_{4} \mathrm{OH}+5 \%\left(\mathrm{NH}_{4}\right)_{2} \mathrm{CO}_{3} \\
3.5 \% \mathrm{NaCl}_{2} \% \mathrm{~K}_{2} \mathrm{CrO}_{4} \\
5 \% \mathrm{NH}_{4} \mathrm{NO} \mathrm{K}_{3} \\
\text { Saturated } \mathrm{KCl}\end{array}$ & $\begin{array}{c}\text { Volt } \\
0.610 \\
.700 \\
.510 \\
\\
.240 \\
.160 \\
.315\end{array}$ \\
\hline
\end{tabular}

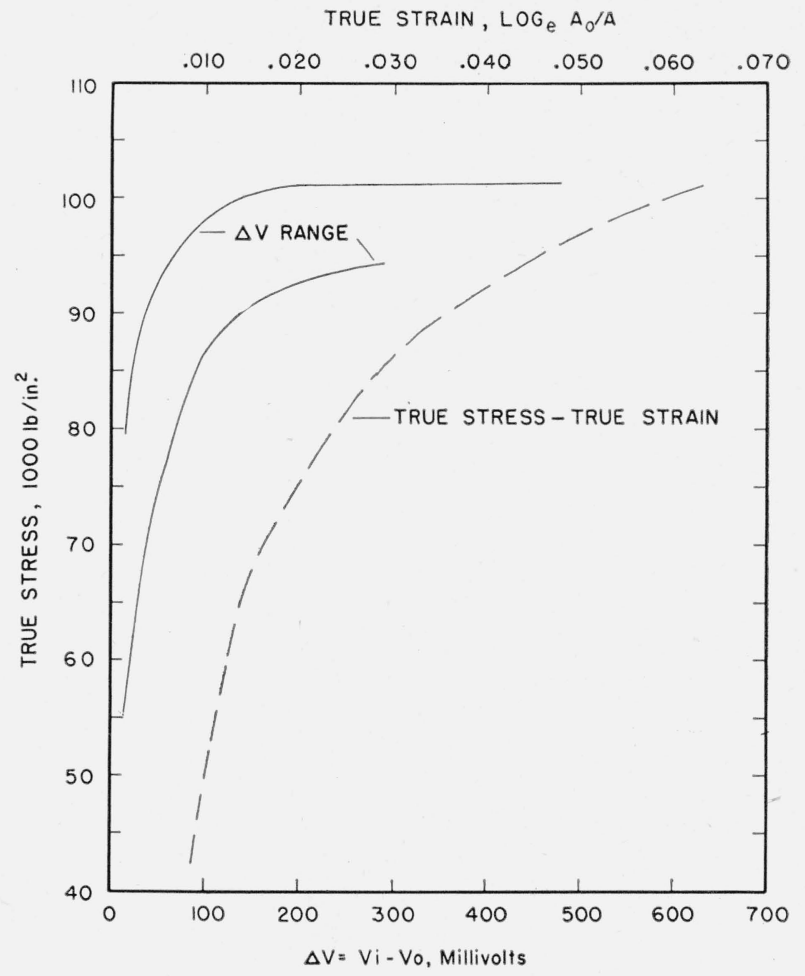

FIGURE 3. True stress-electrochemical solution potential relationships for 24S-T4 aluminum alloy specimens.

Corroding medium, saturated $\mathrm{KCl}$. Data are from seven specimens.

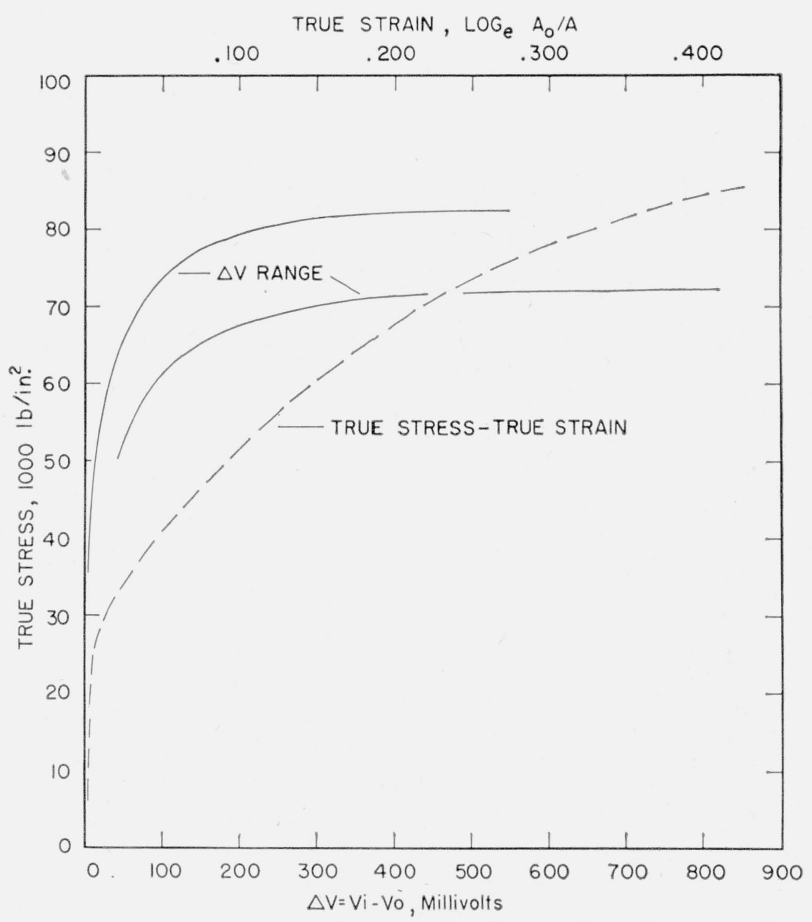

FIGURE 4. True stress-electrochemical solution potential relationships for 70 percent $\mathrm{Cu}-30$ percent $\mathrm{Zn}$ cartridge brass.

Corroding medium, 5 percent $\mathrm{NH}_{4} \mathrm{OH}+5$ percent $\left(\mathrm{NH}_{4}\right)_{2} \mathrm{CO}_{3}$. Data are from seven specimens. 
necessarily the integrated potentials over the entire area in contact with the electrolyte. It is therefore to be expected that potential measurements made on notched specimens of the same material may vary somewhat from specimen to specimen, hence the ranges of potential at given true stresses rather than average curves are shown in the graphs.

There was an appreciable change in the solution potential of the aluminum alloy (fig. 3) at stresses at which the true stress-true strain curve deviated from the modulus line, that is, at stresses at which plastic deformation had occurred. Marked changes in the potentials of the brass specimens (figs. 4 and 5) occurred at stresses that were 10,000 to $25,000 \mathrm{lb} / \mathrm{in}^{2}{ }^{2}$ above those at which the true stress-true strain curves deviated from the modulus line. The solution potential of the magnesium alloy changed appreciable at stresses only about one-third of those necessary to produce deviation from the modulus line (fig. 6). The yield point in the low-carbon steel was accompanied by a marked change in potential (fig. 7). Stresses sufficient to produce a deviation of the true stresstrue strain curve from the modulus line for stainless steel also produced appreciable changes in the solution potential (fig. 8). The electrochemical solution potentials (except for the low-carbon steel) became increasingly more negative as the stresses were increased. For every material (except lowcarbon steel) stresses were reached, as is seen in figures $3,4,5,6$ and 8 , at which the slope of the true stress-potential curves decreased markedly, and the

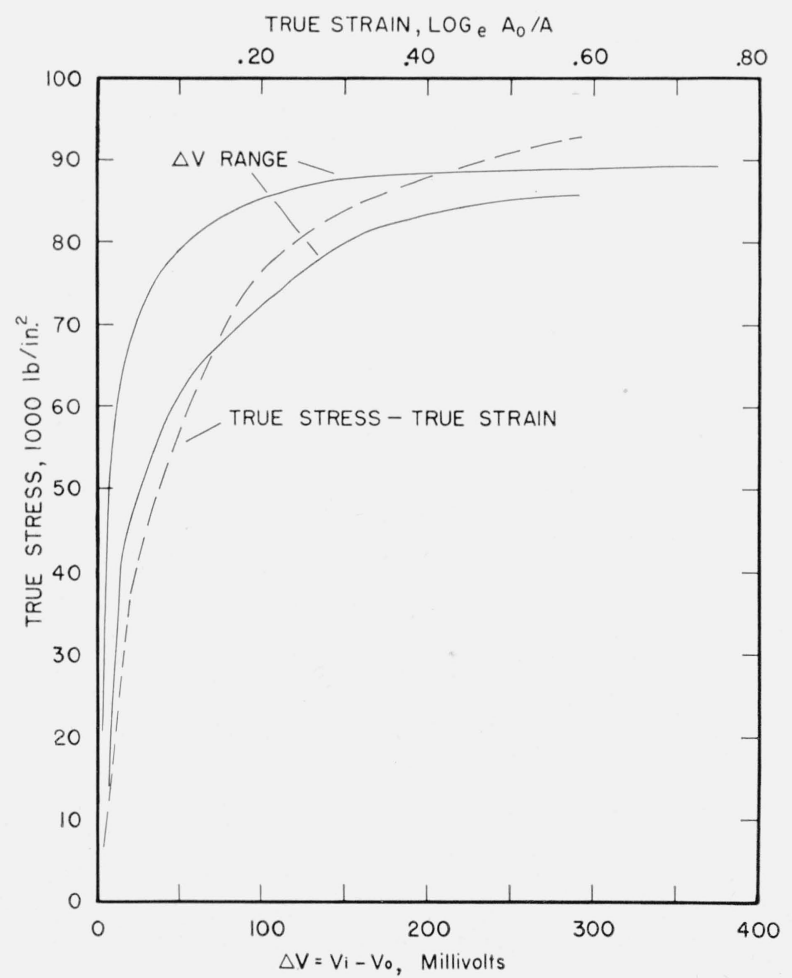

FIGURE 5. True stress-electrochemical solution potential relationships for leaded brass.

Corroding medium , 5 percent $\mathrm{NH}_{4} \mathrm{OH}+5$ percent $\left(\mathrm{NH}_{4}\right)_{2} \mathrm{CO}_{3}$. Data are from five specimens.

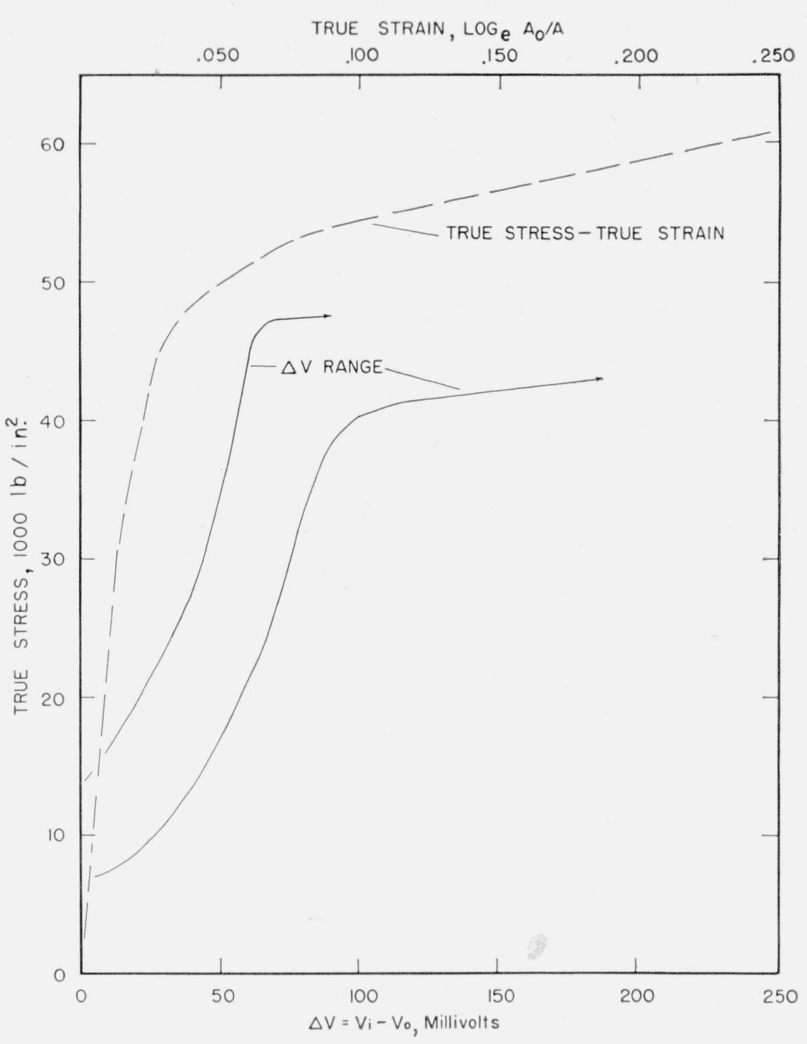

FIGURE 6. True stress-electrochemical solution potential relationships for AZ31 magnesium alloy specimens.

Corroding medium, 3.5 percent $\mathrm{NaCl}+2.0$ percent $\mathrm{K}_{2} \mathrm{CrO}_{4}$. Data are from eight specimens.

potential increased rapidly to the failure of the specimen.

It is postulated that during the loading of the specimens in tension the protective film is broken over minute areas of the surface. If the potential of the unprotected area alone could be measured, it would presumably be of the same order of magnitude as that determined on a film-free surface. The area where the film has been ruptured is very small compared with that of the filmed surface of a specimen, and consequently the measured potential differs by only a small amount from that obtained on an unbroken filmed surface. As the stresses are increased the ratio of the film free to the filmed surface of a specimen increases, and the solution potential becomes more negative, until at the instant of fracture the area of unfilmed surface may be very large compared to that of the filmed surface, and the potential may closely approach that of completely unfilmed material.

At a constant stress the protective film tends to repair itself. This was demonstrated by results obtained on aluminum-alloy specimens. After an appreciable change had been obtained in the solution potential during loading, the applied load was held constant, and within 1 minute the solution potential was the same as that of the unstressed specimen. After the specimens broke (exposing large unfilmed areas) the electrochemical solution potentials rapidly 
assumed the same values as those of the filmed and unstressed materials.

Examination of the fractured surfaces of the notched specimens and the marked changes in the potentials of all of the materials except low-carbon steel at fracture indicated that the final failure had been almost instantaneous. In the low-carbon steel specimens, however, both the appearance of the fracture and the small change in potentials at failure indicated that prior to the final fracture, cracks had penetrated into the material from the roots of the notches and that the progression of fracture was not rapid and was probably discontinuous. Consequently, at failure the amount of freshly exposed unfilmed metal was too small to produce any marked change in the potential.

The data indicate that when the stresses are high enough to cause plastic deformation the atmospherically formed protective film will be broken and the exposed metal will become electronegative with respect to the filmed material. These film-free areas will, in general, be very small compared to the filmed areas. If such areas are connected to filmed areas by a conducting liquid, for example, by a drop of liquid containing dissolved gases or salts, a short-circuited electrolytic cell will be set up, the circuit being com-

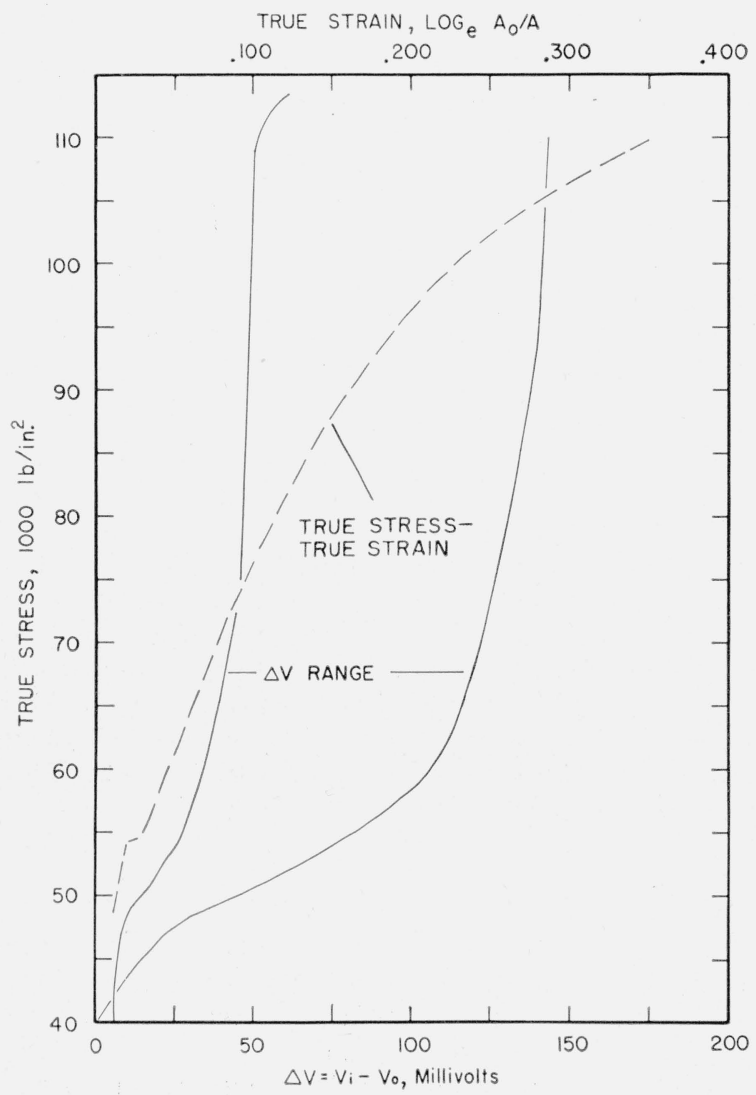

FIGURE 7. True stress-electrochemical solution potential relationships for low-carbon steel.

Corroding medium, 5-percent $\mathrm{NH}_{4} \mathrm{NO}_{3}$. Data are from nine specimens.

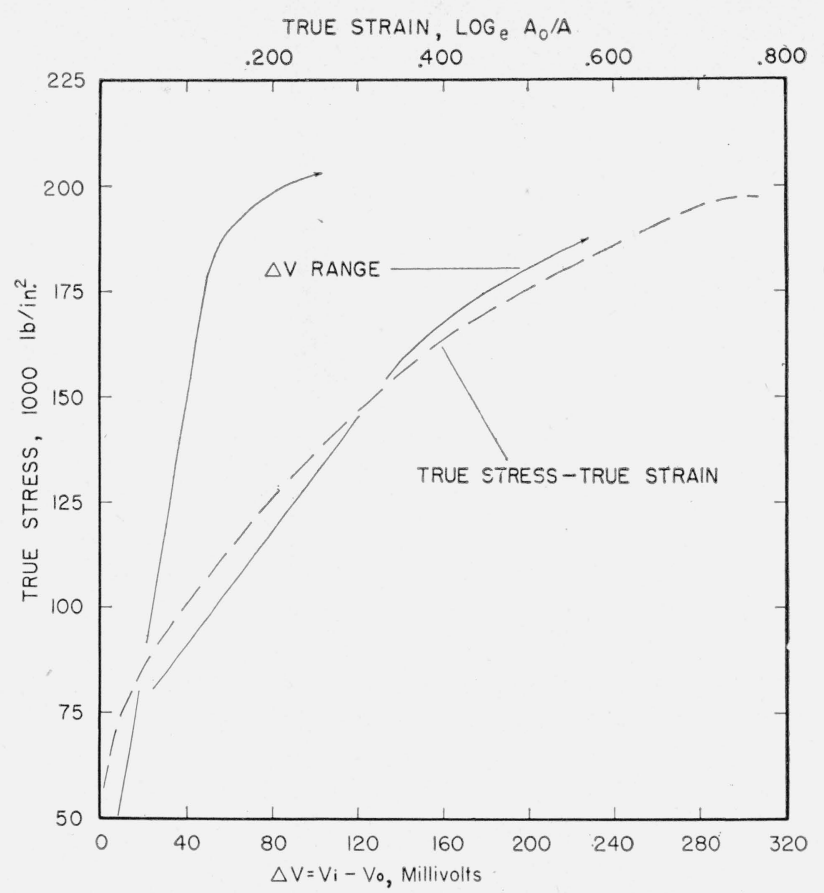

FIGURE 8. True stress-electrochemical solution potential relationships for type 302 stainless steel specimens.

Corroding medium, saturated $\mathrm{KCl}$. Data are from six specimens.

pleted through the metal itself. As the film-free (anodic) area is generally very small compared with the filmed area, the current density over the anodic area will be high, and corrosion will proceed at a rapid rate until a readjustment of stresses permits reforming of the protective surface film. Corrosion will then become more general (or stress corrosion will proceed along different paths) until the stress concentration at the particular path under consideration again becomes sufficient to rupture the protective film. The author believes that successive breaks in the time-potential curves reported by Gilbert and Haden [12] indicate that such processes were occurring, probably at several points, on their test specimens.

The experiments reported in this paper confirm the general idea of the film-rupture mechanism suggested by Mears, Brown, and Dix. In the theory as first presented, it was postulated that tearing of the metal was necessary to expose film-free material. However, the present data indicate that film rupture occurs with comparatively small amounts of plastic deformation of the underlying material. When the film ruptures, stress corrosion may start in the filmfree areas at stresses much below those normally required to tear the metal apart. Unless conditions permit film repair, stress corrosion may progress to cause complete failure in a relatively short time. If the film is restored and the stresses are not increased or readjusted, stress corrosion may cease. If, however, the stresses are readjusted by any means whatsoever, for example, by a change of external load or by corrosion, the film may again be broken and 
stress corrosion proceed discontinuously to failure. The last process may be that which occurs in the transcrystalline type of stress corrosion.

\section{Summary}

As a part of a detailed study of the mechanism of stress corrosion, the electrochemical solution potentials of filmed and film-free surfaces and the true stress-electrochemical solution potential relationships for several alloys were determined.

The electrochemical solution potentials of surfaces, from which the atmospherically formed films had been removed by abrasion in an inert atmosphere, were 0.10 to $0.76 \mathrm{v}$ more electronegative (with respect to a calomel electrode) than filmed surfaces of the same materials.

Appreciable changes in electrochemical solution potentials accompanied plastic deformation, and just prior to fracture the solution potentials were 0.16 to $0.70 \mathrm{v}$ (depending on the alloy) more electronegative than the unstressed material.

The results of the investigation indicate that at stresses sufficiently high to produce failure of the protective film on metals, stress corrosion occurs in a corrosive medium by electrolytic action between film-free (anodic) and filmed (cathodic) areas. The process proceeds continuously or discontinously to failure, depending on whether or not the subsequent adjustment of stresses permits reforming of the protective film.
The author gratefully acknowledges the help of Thomas P. Royston, Jr., in obtaining the data presented in this paper.

\section{References}

[1] Metals Handbook, p. 14, 1948 ed. (Am. Soc. Metals, Cleveland, Ohio).

[2] W. B. Price, Am. Inst. Mining Engrs. 89, 268 (1930).

[3] Symposium on Stress-Corrosion Cracking of Metals, Am. Soc. Testing Materials-Am. Inst. Mining Engrs., 1944 (Am. Soc. Testing Materials, Philadelphia, Pa.).

[4] U. R. Evans, Symposium on Internal Stresses in Metals and Alloys, Inst. Metals, p. 309 (1948).

[5] F. H. Keating, Symposium on Internal Stresses in Metals and Alloys, Inst. Metals, p. 329 (1948).

[6] E. Hugony, Alluminio 17, 225 (1948).

[7] C. A. Zapffe, Trans. Am. Soc. Mech. Eng. 66, 81 (1944).

[8] H. P. Croft and G. Sachs, Iron Age 151, 47 (March 11, 1943); 151, 62 (March 18, 1943).

[9] H. P. Croft, Proc. Am. Soc. Testing Materials 41, 905 (1941)

[10] J. J. Harwood, Corrosion 6, 249 and 290 (1950).

[11] R. B. Mears, R. H. Brown, and E. H. Dix, Jr., Symposium on Stress-Corrosion Cracking of Metals, Am. Soc. Testing Materials-Am. Inst. Mining Engrs., p. 329, 1944 (Am. Soc. Testing Materials, Philadelphia, Pa.).

[12] P. T. Gilbert and S. E. Haden, J. Inst. Metals $\mathbf{7 y ,} 237$ (May 1950)

[13] H. L. Logan, J. Research NBS 25, 315 (1940) RP1328.

[14] R. B. Mears and R. H. Brown, Ind. Eng. Chem. 33, 1001 (1941).

[15] Y. Druet and P. A. Jacquet, Metaux \& Corrosion 22, 139 (1947)

Washington, October 1, 1951. 